\title{
Design and Implementation of Online Fashion Store "Demi Outfits" Based on Android
}

\author{
Yana Hendriana \\ Department of Informatics \\ Universitas Ahmad Dahlan \\ Yogyakarta, Indonesia
}

\author{
Richki Hardi \\ Department of Informatics \\ STITEK Bontang \\ Bontang, Indonesia
}

\author{
Andri Pranolo \\ Department of Informatics \\ Universitas Ahmad Dahlan \\ Yogyakarta, Indonesia
}

\begin{abstract}
Android technology developments that are currently able to occupy the highest positions of gadgets and computer market, it is certainly due to the sophistication of technology information and applications that are on it that is currently a trend among mobile users because it can help all areas of the job so much easier. The purpose of Technopreneurship in the field of Design and implementation of online fashion store based on android is designed to assist in the sales transaction of business units called "Demi Outfits" has been established since 2013, making it easier for the android-based online transactions. Thus the computer tools and android smartphone is necessary given the various transactions were originally done manually. Given these tools various transactions can be completed quickly and efficiently than when using a manual system. To expedite the process of search services and purchases by customers towards these online stores, we need a system that allows customers to access the service online stores, especially the process of buying fashion online using android based mobile applications store. This application will also provide facilities that assist in the search for collection until the transaction purchases by customers. The system will tell to customers whether the collection to be purchased is available or not and their status are trends or expired.
\end{abstract}

Keywords: Android; fashion; mobile; store; online; technopreneurship

\section{INTRODUCTION}

People need jobs to earn a living and meet daily needs. Among these men there who have the ability to establish their own jobs and be hired for other human beings as selfemployed, to meet an advantage in setting up the business and is always ready to accept failure or loss on such business [1].

Purchasing fashion in society at large still manually, each person must come directly to the fashion store. For those who are busy with activity and employment, the purchase method is time consuming and labor making it less effective and efficient. Most of them do not have a vehicle, so it cannot buy clothes because of these constraints. In terms of business, the market share of conventional fashion store business is still less extensive [3].

A variety of technological devices developed and used to support the achievement of the marketing process in the field of entrepreneurship. Currently, efforts are developed to store business that is using accessing websites via the Internet [2]. It is still a weakness because not everyone can use the webbased applications and not everyone has a computer that can access to the internet.

To expedite the process of search services and purchases by customers towards these online stores, we need a system that allows customers to access the service online stores, especially the process of purchasing fashion online using android based mobile store applications. This application will also provide facilities that assist in the search for collection until the transaction purchases made by customers. The system will tell you whether the collection available to be purchased or not and their status are trends or expired.

Android is an operating system for mobile phones based on Linux. Android SDK (Software Development Kit) provides the tools and API (Application Programming Interface) that is necessary for developers to create and develop applications that use the Android operating system on mobile phones using the Java programming language [4].

\section{RELATED WORKS}

The unique and novel, mobile and online based ordering and reservation platform and system, for such time sensitive services, provides the mobile phone and Internet users and various types of business owners with comprehensive sets of options, including the mobile phones installed with the open source "Android" software platform developed by the "Open Handheld Alliance (OHA), such as the "gPhone" released by "Google", to deliver the requests and responses automatically and instantly through means of synchronization between mobile and Internet communications. Based on the open source mobile phone platform and the Internet server infrastructure, an intuitive and easy-to-use mobile phone and online based ordering and reservation management system is uniquely defined in the architecture of the current invention to allow both the business owners and end consumers with real time communications for a plural of mobile and online ordering and reservation services [6]

The study also adds what are argued to be key consumer characteristics such as Opinion Leadership, Impulsiveness, Web Shopping Compatibility, Internet Self-Efficacy, Perceived Web Security, Satisfaction with web sites, and Shopping Orientation to understand the adoption of Web retailing by Internet users'. A Web based survey was developed and administered, yielding 392 responses. The findings indicate that TAM is a valid theoretical framework to understand users adoption of the Web for retail purposes. Also Internet users' perceived usefulness and perceived ease of use were effected differentially by Opinion Leadership, Web Shopping Compatibility, Internet Self-Efficacy, Perceived Web Security, Impulsiveness, Satisfaction with web sites, and Shopping Orientation [7].

Electronic commerce typically lacks human warmth and sociability, since it is more impersonal, anonymous and 
automated than traditional face-to-face commerce. This paper explores how human warmth and sociability can be integrated through the web interface to positively impact consumer attitudes towards online shopping. An empirical study was undertaken to investigate the impact of various levels of socially rich text and picture design elements on the perception of online social presence and its subsequent effect on antecedents of attitudes towards websites. Higher levels of perceived social presence are shown to positively impact the perceived usefulness, trust and enjoyment of shopping websites, leading to more favourable consumer attitudes. Implications of these finding for practitioners and future research are outlined [8].

\section{OVERVIEW OF BUSINESS}

\subsection{Structure of Business}

Here is a general overview of the business plan, including market opportunity of this business.

\subsubsection{Product Analysis}

1). Type, Name, and Product Characteristics Types of products produced from this business, ie fashion for men, women and children, that are direct marketing and online-based Android.

2). The advantages of the product compared to other products on the market

Products on offer has several advantages, ie :

- The online fashion store business marketing using android based smartphone.

- Purchases fashion does not need to come directly to the store

3). Linkages with other products including Raw Material Processing

In this online fashion store business, requires some stuff and cooperation among others :

1) Computer

2) Printer

3) Papers

4) Internet Connection

5) Cooperation with the ISP for Android Database Server.

6) Cooperation with manufacturers / producers and other fashion stores.

7) Motorcycle for delivery order.

\subsubsection{Market Analysis}

1). Consumer Profile

- Teens with fashion as a form of habit needs to follow fashion / latest trends.

- People usually need to add fashion collection as well as a birthday present and also trends of Eid or Lebaran.

2). Potential and Market Segmentation

Segmentation useful in online stores, among others:

- The effectiveness of promotion, because different segments approached in a different way

- Could save as focusing first to work on a more important segment, which is the main market

- Different segments can be influenced by different promotional media, there are detik.com banner, republika.com banner or news portal for women

- Can be measured on what is most needed from each segment, can be a way sample contact time of purchase at the online store

- Determining an effective way to send items, cheap and fast

\subsubsection{Target and Strategy Analysis}

1). Marketing Target

The target of our efforts are aiming for the middle market, where we sell products to all people, from the kids, Youth, up to adults. And we prepare for its online product that is ready to pack in packaging that has a neat and attractive.

2). Marketing Strategy

- Product Development

Creating a better product in terms of taste and crispness that has high quality to be able to attract consumers to consume our products

- Marketing Development

Development in the area around the place of production, the campus, as well as the internet such as facebook, twitter, fanspage, blogspot and Android

- Promotion Activity Promoting products through a friend to a friend, sales, and through social media.

- Product Pricing

Our products set the price based on capital and raw materials used.

\subsection{Description of Business}

Developments and advances in the field of competition in fashion. Business carried on in the field of fashion can help improve the effectiveness and efficiency of the implementation of Technopreneurship, especially in entrepreneurship, in order to produce a good entrepreneur with a technology based. This effort is managed now selling fashion men, women and children. In carrying out this effort consists of 4 people. The purpose of Technopreneurship in the field of Online Fashion Store is based on Android is designed to assist in the sales transaction of business units called "Demi Outfits" has been established since 2013 in Yogyakarta Indonesia.

\subsubsection{Business Capital}

Initial capital to start the business came from the cooperation with business owners T-shirt and shirt. The products we sell are from convection located area of Yogyakarta and Bantul. We deliberately took the product from there because the prices of the products are very cheap compared to convection if you buy products on the market.

Our group got the confidence to sell products shirt with the following details:

- Initial Capital : 10 pieces of clothing @ $70,000=$ IDR. 700,000

- Final Capital : 7 pieces of clothing @ 70,000=IDR. 490,000

Breakdown of sales :

Area Sales : Campus

Customers : Student

Time to market : 1 Day

- Sale : 3 pieces of clothing @ $90.000=$ IDR. 270.000

- Income derived from the sale of 3 pieces of clothing (a) $20.000=$ IDR. 60.000

After our business run for 1 year, with directly marketing or by way of rental booths in exhibition events in all areas of Java and Bali, the development and the results have to be felt, in one exhibition for 1 week has been getting average turnover of 70 million.

\subsubsection{Marketing / Promotion}

Business that we do now widely seen in anywhere. Business Developments in Indonesia is greatly increased, in addition to 
capital is not too large the benefits are enormous. Besides the growing consumer demand for price comparison much cheaper than the existing malls in Indonesia. In a business competition is a competition in the business world. With the proliferation of business at this time led to intense competition between employers, for the more we work around this by prioritizing the quality of the product. In selling products, we are looking for a more lively and is the main place most women. Looking for a strategic place, safe, lively and accessible location to consumers.

1). Personal Selling

In addition to the products that we offer by way of resellers, we also offered directly to consumers with a variety of marketing communications of the products we offer, such as from hand to hand and from mouth to mouth information that we think is more convincing than advertise in electronic media.

2). Advertising

We also offer other than through personal selling well past the line advertising fanpage on facebook, twitter, personal blogs, and android smartphones. In this activity we offer online sales with the aim of getting people's participation to the products we offer.

\subsubsection{Product Samples}

1). Production Process

Process of product done in production house using quality raw materials and ancillary equipment as shown in fig. 1

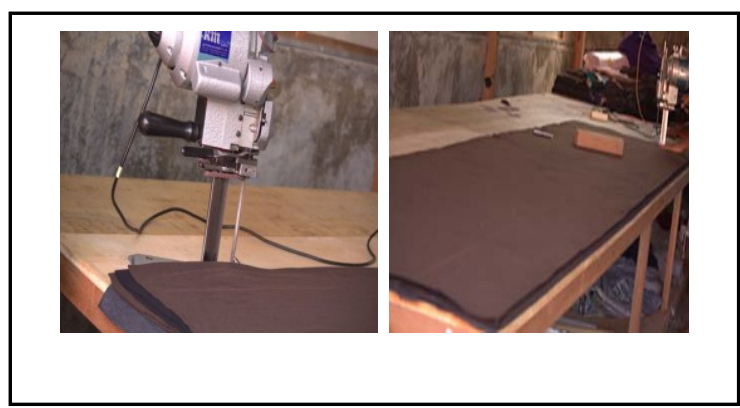

Fig. 1 Production Process

2). Design for teenage boys

Attractive fashionable and follow the trend fashion and clothing model emerging, must have a trend of its own for the age group of teenagers, especially in teenagers friendships, absolute fashionable to be noticed as shown in fig. 2

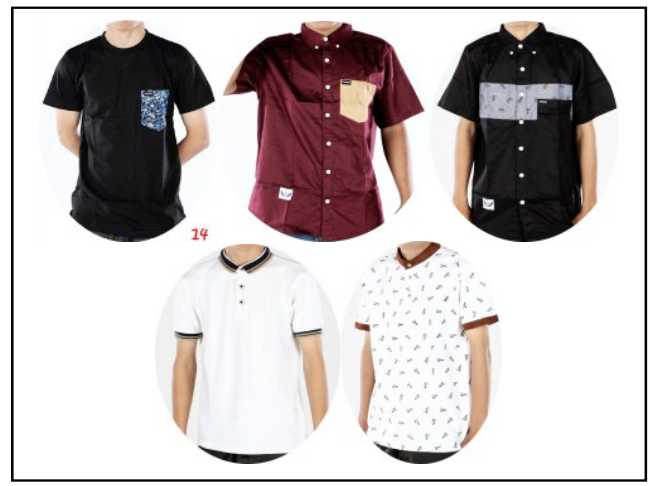

Fig. 2 Design for teenage boys

\section{RESULTS}

\subsection{Connectivity Analysis}

Applications of online fashion store that build consists of two parts. First, the server side is composed of website creation and store administrator. Second, the client side is an Android based applications. General overview of the application system can be seen in Fig. 3 .

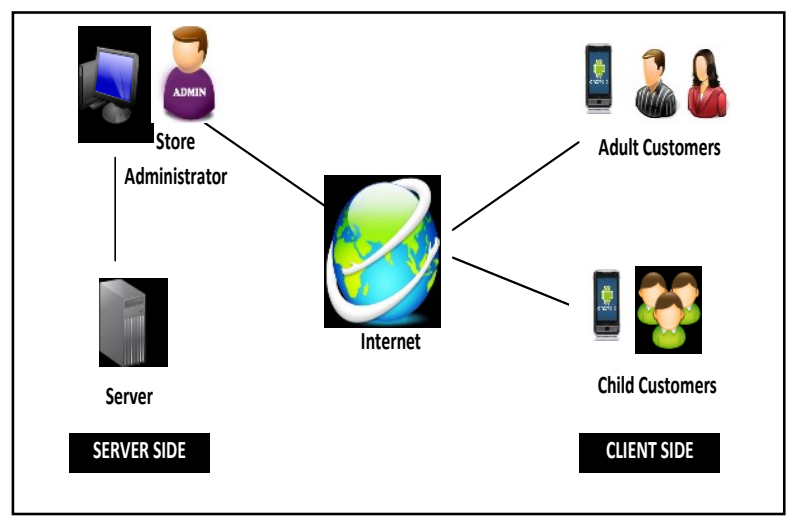

Fig. 4 Architectural Systems of Online Store

\subsection{Design Analysis}

Android Application Design consists of many activity. Activity are related to one another [5]. Collection activity listview activity that has a single function displays a three fashion categories. The displays a wide range of fashion collections by fashion category selected in the form of listview in fashion list. Customer activity is designed to transmit data to the database server buyers. While the order activity report is designed to send order confirmation via email. General overview of The flowchart of order processing services on online fashion store can be seen in Fig. 4

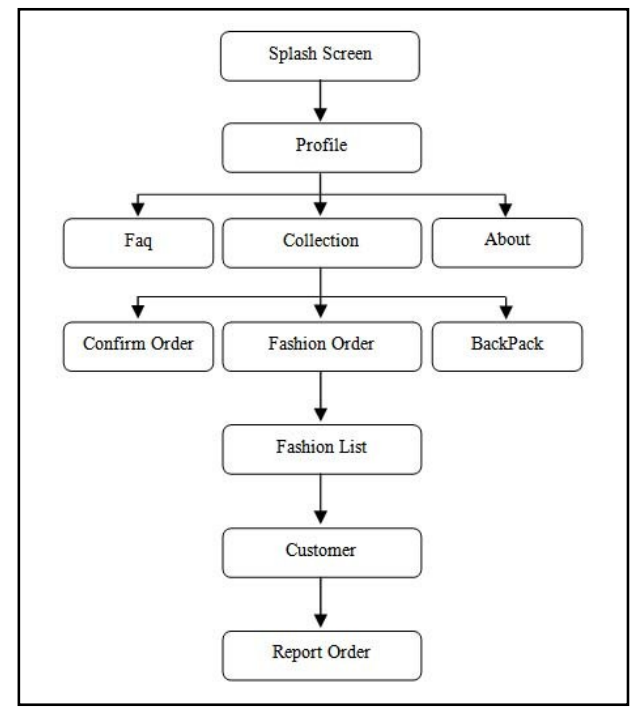

Fig. 4 Flow of order processing services

The connection between customers android smartphone users with a server in Fig. 3, the process will request the URL to the server. The server will perform a query according to the fashion category. The next stage of the application process to be displayed to the user in a list. Then the customer can fill out the form to find out the identity of the customer information do order items. The information is used as a container of the administrator to send a confirmation and checks the transaction. Furthermore the customer to confirm 
the order. The tangible confirmation email sent to the administrator and the customer. Applications using GMAIL as the SMTP email sender media.

\subsection{Implementation System}

Implementation of the system is the stage of putting the system in accordance with the design that has been created and is ready to operate. This phase is done after doing system design that is making the program. Display applications have been made as the following:

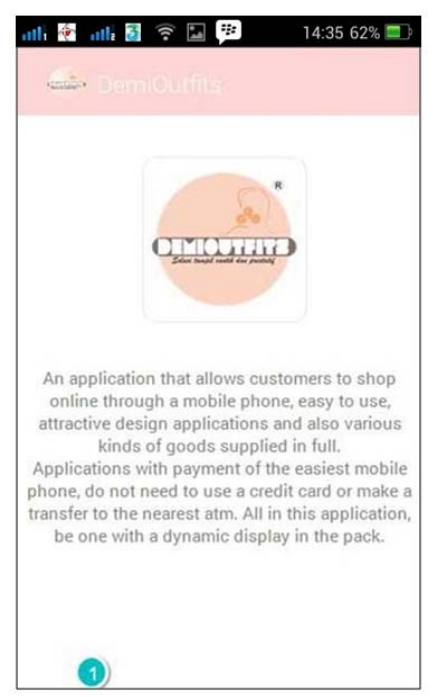

Fig. 5 Splashscreen

Fig. 5 shows the basic features in this application, splashscreen is the first page that appears when the application is run the online fashion shop based on android. This page is a splash page when the application runs. Splashscreen page consists of View "Demioutfits" Logo, and TextView.

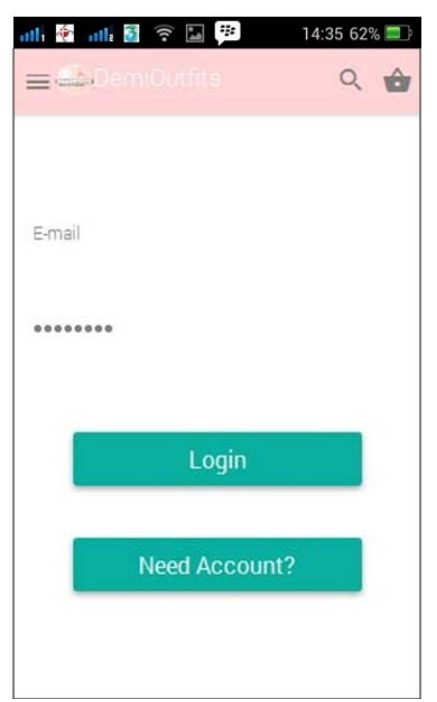

Fig. 6 Login Menu

Fig. 6 shows view of loginmenu as an initial menu. On the Login menu the user can enter into the system. If users do not already have an account then be able to register first in order to have the account password through "Need Account" button.

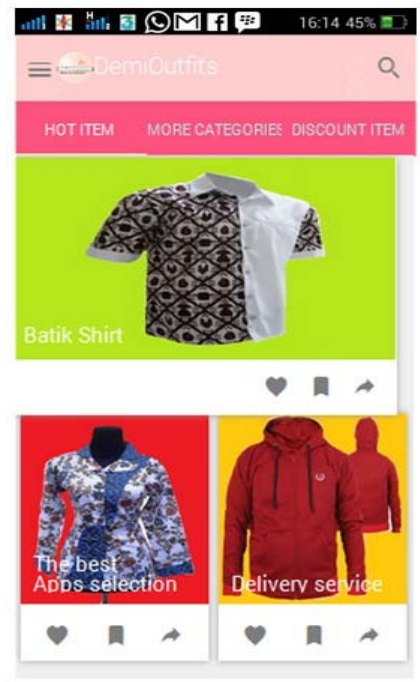

Fig. 7 List Product of Hot Item

Fig. 7 shows List product of Hot Item in the main page. On the main page there are 3 menu options that can be selected by the user, namely: Hot Item, More Categories, Discount Item.

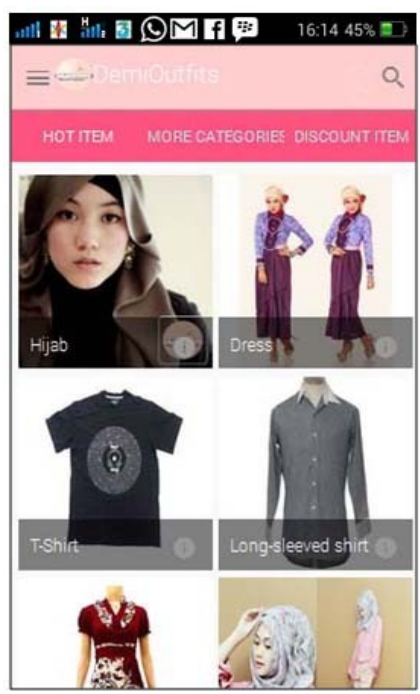

Fig. 8 List Product of More Categories

Fig. 8 shows List product of More Categories. On the More Categories there are more item of product offered to users. to display the product detail the user can select / click the product image. 
International Journal of Computer Applications Technology and Research

Volume 4- Issue 6, 438 - 443, 2015, ISSN:- 2319-8656

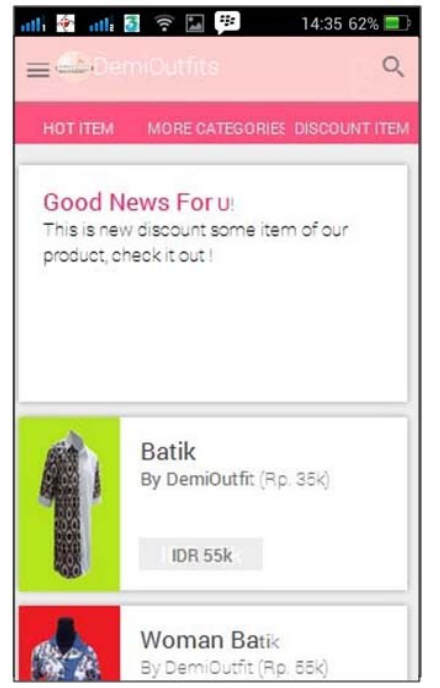

Fig. 9 List Product of Discount Item

Fig. 9 shows List product of Discount Item. On the Discount item there are promo products at discounted prices, users can observe the comparison of normal price and discount price. to display the product detail users can select / click the product image.

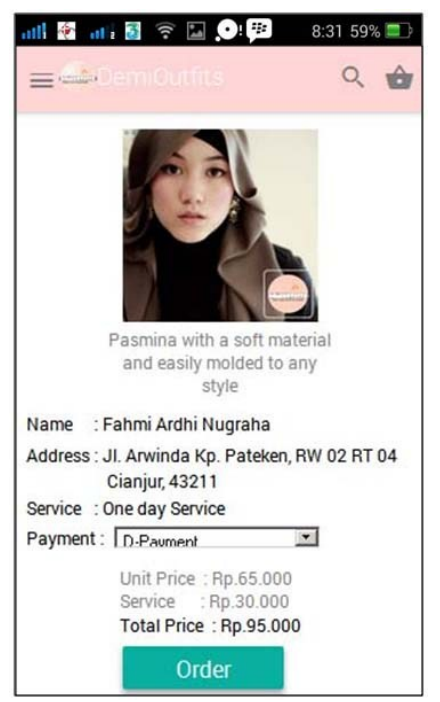

Fig. 10 Purchase Order

Fig. 10 shows the facility of purchare order for 1 product namely "Pasmina", the name of buyer is Fahmi Ardi Nugraha who use type of payment is D-Payment. Total Price of order is IDR. 95.000.

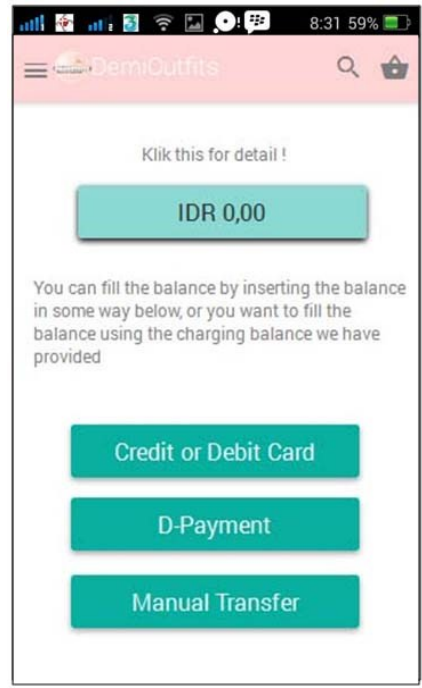

Fig. 11 Types of Payment

Fig. 11 shows types of payment which consists 3 types of payment option among others "Credit or Debit Card", "DPayment", and "Manual Transfer". User can choose one of payment option according to the types of payments that are expected.

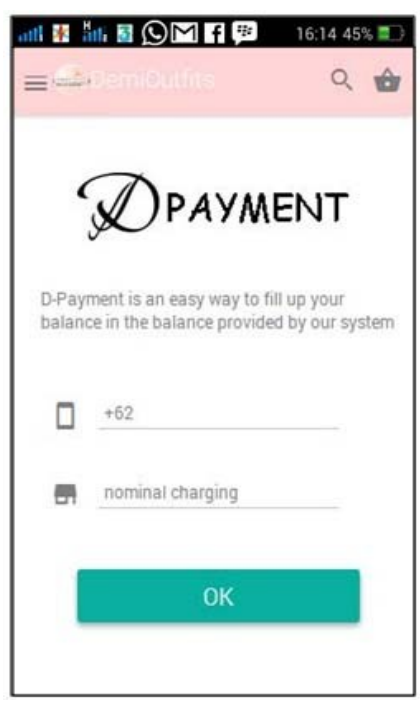

Fig. 12 D-Payment

Fig. 12 shows one of types of payment namely D-Payment, DPayment is derived from the "Deposit Payment", payment by reducing the deposit balances in deposit accounts belonging to the user is stored in the database server "Demi Outfits". 


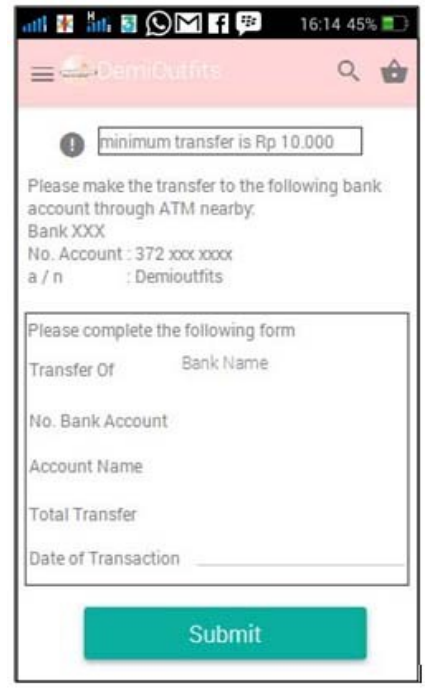

Fig. 13 Manual Transfer

Fig. 13 shows one of types of payment namely Manual Transfer, Manual Transfer is payments made by way of bank transfer, whether it is done at the teller or ATM to the bank account of "Demi Outfits".

\section{CONCLUSIONS}

Based on the results of the analysis, design and implementation has been done before, it can take several conclusions, among others:

1). In the making of this application the first step is to upload the data is needed on webservice. So that applications can take or parsing the data needed.

2). The displays a wide range of fashion collections by fashion category selected in the form of listview in fashion list.

\section{REFERENCES}

[1]. Lappalainen, J., Niskanen, M., 2013. Behavior and attitudes of small family firms towards different funding source. Journal of Small Business \& Entrepreneurship, vol. 26, issue 6, (pp. 579-599) .

[2]. Castrogiovanni, F. G., Peterson, M. F., 2012. Developing High-Tech Ventures: Entrepreneurs, Advisors, and the Use of Non-Disclosure Agreements (NDAs). Journal of Small Business \& Entrepreneurship, vol. 25 , issue 1, (pp. 103-119)

[3]. Pujiyono, W., Rahardianti, E. D., 2009. Aplikasi Toko Buku Online Berbasis SMS Gateway Over GPRS. Seminar Nasional Aplikasi Teknologi Informasi 2009 (SNATI 2009), ISSN: 1907-5022, (pp. B1-B6).

[4]. Safaat, N.., 2012. Android, Pemrograman Aplikasi Mobile Smartphone dan Tablet PC Berbasis Android edisi revisi. Publisher Informatika, Bandung

[5]. Putra, P. K, Santoso, P., 2013. Aplikasi Toko Tas Online Berbasis Android. Jurnal Dimensi Teknik Elektro Vol. 1, No. 1, (pp. 12-17).

[6]. HONG, Jin; ZHANG, Qihong Nicki, 2008. Open Mobile Online Reservation and Ordering Systems. U.S. Patent Application 12/344,596,

[7]. O'cass, A., \& Fenech, T., 2003. Web retailing adoption: exploring the nature of internet users Web retailing behaviour. Journal of Retailing and Consumer services, 10(2), 81-94.

[8]. Hassanein, K., \& Head, M., 2007. Manipulating perceived social presence through the web interface and its impact on attitude towards online shopping. International Journal of Human-Computer Studies, 65(8), 689-708. 